\title{
The Impact of Intelligent Manufacturing on Export Sophistication: Evidence from Industrial Robots
}

\author{
Lihua $\mathrm{Gu}^{1}$ \\ ${ }^{1}$ School of International Trade and Economics, Central University of Finance and Economics, P. R. China \\ Correspondence: Lihua Gu, School of International Trade and Economics, Central University of Finance and \\ Economics, Beijing 100081, P. R. China. E-mail: gulihua0308@163.com
}

Received: September 29, 2019

Accepted: October 22, 2019

Online Published: November 12, 2019

doi:10.5539/ijbm.v14n12p183

URL: https://doi.org/10.5539/ijbm.v14n12p183

\begin{abstract}
We analyze the relationship between intelligent manufacturing and export sophistication from the perspective of industrial robots. We use industrial robot panel data from International Federation of Robotics in 70 countries from 1995 to 2016. Our empirical research shows that if a country increases $1 \%$ of industrial robots in production process, export sophistication will increase $0.0036 \%$. The result is very robust when we use two kind of proxy variables. And we also find that financial crisis depresses the effect of industrial robots on export sophistication. Our estimates suggest that intelligent manufacturing is a way to realize export upgrading in the background of a new industrial revolution. Countries without producing any industrial robots can import some robots from other countries to increase export sophistication.
\end{abstract}

Keywords: Intelligent manufacturing, export sophistication, industrial robots

\section{Introduction}

Export sophistication is a kind of export upgrading. An exporting product with high export sophistication means it is of high technology or quality. Therefore more and more countries strive to increase export sophistication. In the background of a new round of scientific and technological revolution, artificial intelligence (AI) and robots make great progress. Many countries, especially developed countries, take actions to cope with changes of new technologies. They initiate amount of strategic policies, such as Industrial 4.0 of Germany, Strategy for American Leadership in Advanced Manufacturing, New Industrial French Strategy, Made in China 2025 strategy and so on. All of these policies are focused on intelligent manufacturing, which means intelligent technologies are applied to production system. The production processes become more automatic or intelligent.

Nowadays industrial robots are widely used in production process to promote intelligent manufacturing. Figure 1 shows the number of shipment robots in the world from 1993 to 2017 and the data are from International Federation of Robotics (IFR). We can know that units of industrial robots are continuously increased. Industrial robots was increased by $30 \%$ to about 3800 thousand units around the world in 2017. But there was a large drop in 2009, because of financial crisis. According to IFR, China has been the biggest market since 2013. In 2017, China installed a share of $36 \%$ in the total industrial robots, more than 137 thousand units. Besides China, Japan, the Republic of Korea, the United States and Germany are also other major big markets. Robot density is the number of industrial robots in manufacturing process per 10,000 workers. In 2017, the average robot density in the manufacturing industry was 85 industrial robots per 10,000 employees. The Republic of Korea, Singapore and Germany were top three high robot density countries in 2017. China had 97 industrial robots per 10,000 employees, lower than many developed countries. 


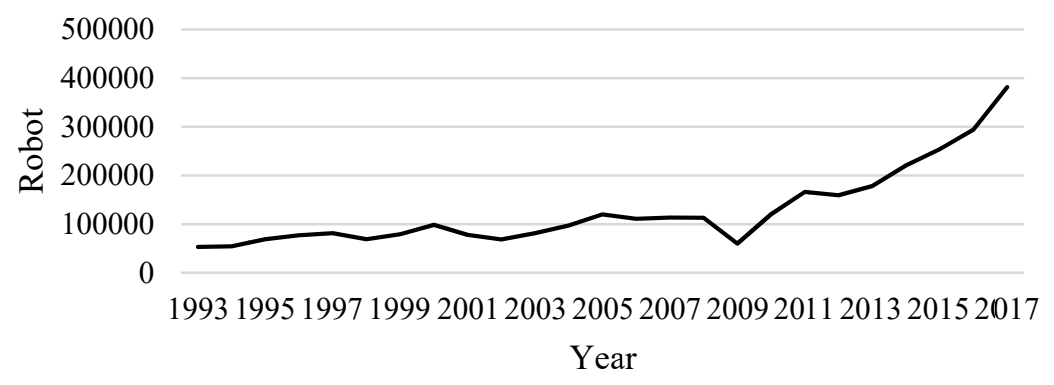

Figure 1. The shipment number of industrial robots in the world from 1993 to 2017

Source: International Federation of Robotics.

A new round of scientific and technological revolution is coming. Does intelligent manufacturing promote export sophistication? This paper will investigate whether intelligent manufacturing impact export sophistication from the perspective of industrial robots. The rest of paper is organized as follows. The first part is about a literature review of export sophistication and intelligent manufacturing. In the second part, an economic model is established. Then empirical results and robust checks are given. The final part is a conclusion of this paper.

\section{Literature Review}

An important determinant of China's rapid growth is a more sophisticated export basket (Rodrik,2006). Therefore lots of researchers find that export sophistication promotes economic growth. Jarreau et al (2012) think that ordinary export activities play a more important role in export sophistication to drive growth. Mishra et al (2011) find that there is a positive relationship between per capita income growth and service export sophistication. Sophisticated products can promote the upgrading of a country's exports. What do factors affect export sophistication? Weldemicael's (2014) paper shows if a country has high technology and low trade cost, it will have a high-level export sophistication. So low-income countries more need to take actions to increase technology and cut trade cost. Cultural diversity in a country has an impact on export sophistication(Fan et al,2018). There is also a positive relation between FDI and export sophistication, but the magnitude of FDI is larger for developing countries than in high income countries(Harding et al,2009). Besides that, human capital, trade liberalization and intellectual property rights also affect a county's export sophistication(Spatafora et al,2012; Zhang and Yang,2016).

Although many factors affect export sophistication, there is no literature about if intelligent manufacturing affects export sophistication. Intelligent manufacturing has a great impact on economic development. Zhong et al.(2017) think in the generation of Industry 4.0, manufacturing is with better quality and higher productivity. Acemoglu and Restrepo(2018a) develop a framework for the impact of AI and robots on the demand for labor, wages and employment. They find that AI and robots replace workers in routine work, decrease wages, increase output per worker and also increase the demand for labor in non-automated tasks. As DeCanio (2016) estimates that if the elasticity of substitution between human and robotic labor is bigger than 1.9, AI technologies will decrease aggregate wages. Frey and Osborne (2017) think around 47\% of total US employment could be automated soon. But Acemoglu and Restrepo (2018a) also think when machines replace labor, new tasks are appearing. Berg et al. (2018) think artificial intelligence and robotics open up more opportunities than they close and labor force skills keep up, so we don't worry about. Atkinson and Ezell (2019) believie AI and automation do not replace people but rather combine their capabilities in new ways to create new forms of value and new opportunities. Although robots decrease production cost or increase productivity, inequality may increases during transitions driven by faster automation (Costinot \& Werning, 2018; Acemoglu \& Restrepo, 2018a; Hemous \& Olsen, 2014). Factories introducing machines in production process may create winners and losers, so governments need to make policies such as putting a tax on robots (Costinot \& Werning, 2018). If robots replace unskilled workers, developing countries' long-term comparative advantage of cheap labor costs will be weakened and their labor-intensive industries will be lost. Berg et al. (2016) think the share of capital in production factors will be bigger, while labor share will be smaller in the age of robots.

Literature shows us there are extensive researches on export sophistication or intelligent manufacturing. But there is relative few evidence on the implication of intelligent manufacturing on export sophistication. Our study is to remedy this problem, by analyzing how widely-used robots affect export sophistication. There are three 
contributions in our paper. We firstly research the relationship between intelligent manufacturing and export sophistication in the background of a new industrial revolution. We use the data from International Federation of Robotics to analyze the relationship from the perspective of shipment robots in different countries. And we can give another economic effect of intelligent manufacturing apart from other economic effects such as productivity, employment, production cost and so on. This is also a supplement to existing literature.

\section{Methodology}

\subsection{Economic Model}

In this paper, following economic model is established. We also add some control variables, which affect export sophistication in the model.

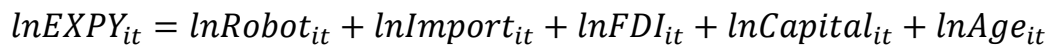

$$
\begin{aligned}
& + \text { lnHighed } u_{i t}+\mu_{i}+v_{t}
\end{aligned}
$$

In equation (1), EXPY represents a country's export sophistication. Robot is the quantity of shipment industrial robots in the country. Import is the percent of import (both goods and services) in GDP. FDI is the percent of inward stock foreign direct investment in GDP. Capital is the share of gross capital in GDP. Age is the percent of population ages 65 and above in total population. Highedu is the tertiary education ratio of total enrollment. We take the $\log$ of all the variables. In early years, some countries didn't install any industrial robots, then quantity of shipment industrial robots was zero. If we directly log of quantities, some samples will be missing. Then we take $\log$ of quantities with plus one. $i$ represents a country and $t$ represents a year. $\mu_{i}$ and $v_{t}$ respectively mean country effect and year effect.

According to Rodrik (2006), indicator of export sophistication is constructed. Export sophistication represents the technical content of a country's exports. We measure it through two steps. Firstly, we calculated export sophistication of product $k$ in country $i, P R O D Y_{i k}$. In equation (2), the numerator $x_{i k} / \sum_{k} x_{i k}$ is the share of product $k$ in the total export of country $i$. The denominator $\sum_{i}\left(x_{i k} / \sum_{k} x_{i k}\right)$ is the sum of the export share of product $k$ for all countries. $Y_{i}$ is the per capita GDP of country $i$. Secondly, we calculated export sophistication of country $i, E X P Y_{i}$. In equation (3), we sum each export sophistication of product $k, P R O D Y_{i k}$, with the weights $x_{i k} / \sum_{k} x_{i k}$.

\subsection{Data}

$$
\begin{gathered}
P R O D Y_{i k}=\sum_{i} \frac{x_{i k} / \sum_{k} x_{i k}}{\sum_{i}\left(x_{i k} / \sum_{k} x_{i k}\right)} Y_{i} \\
E X P Y_{i}=\sum_{k} \frac{x_{i k}}{\sum_{k} x_{i k}} P R O D Y_{i k}
\end{gathered}
$$

The data used to measure export sophistication are from BACI database of CEPII. BACI provides bilateral trade data at the HS1992 6-digit product disaggregation for more than 200 countries from 1995 to 2016. The data of industrial robots are from IFR. It provides flow and stock of shipment of robots for 75 countries or regions since 1993. Here we first use the flow of shipment robots in the basic regression and use the stock value in the robustness test. The IFR calculates the multipurpose manipulating industrial of robots, defined by the International Organization for Standardization (ISO: 8373). So we can compare the number of robots across countries. The data of the percent of imports in GDP, the share of gross capital in GDP, the percent of population ages 65 and above in total population and the tertiary education ratio of total enrollment are all from world bank WDI database. The percent of inward stock foreign direct investment in GDP is from United Nations Conference on Trade and Development. For consistency, we use 70 countries and regions from 1995 to 2016 in our sample.

Table 1 reports the summary statistics of all variables. Figure 2 is scatter plot of EXPY and Robot and we also add a fitted line in the figure. From the figure, we can know that a positive correlation is between export sophistication and robot. If a country installs more industrial robots, it will get a higher export sophistication. Then its export is more competitive or gets upgraded. 
Table 1. Summary statistics of all variables

\begin{tabular}{llllll}
\hline Variable & Observations & Mean & Standard Deviation & Minimum & Maximum \\
\hline lnEXPY & 1,540 & 9.618 & 0.360 & 8.170 & 10.79 \\
lnRobot & 1,540 & 3.278 & 3.294 & 0 & 11.37 \\
InImport & 1,508 & 3.616 & 0.571 & 2.042 & 5.398 \\
lnIFDI & 1,521 & 3.143 & 1.124 & -2.049 & 7.502 \\
lnCapital & 1,510 & 3.156 & 0.267 & -1.301 & 3.889 \\
lnAge & 1,540 & 2.203 & 0.680 & -0.287 & 3.280 \\
lnHighedu & 1,224 & 3.714 & 0.640 & 1.002 & 4.839 \\
\hline
\end{tabular}

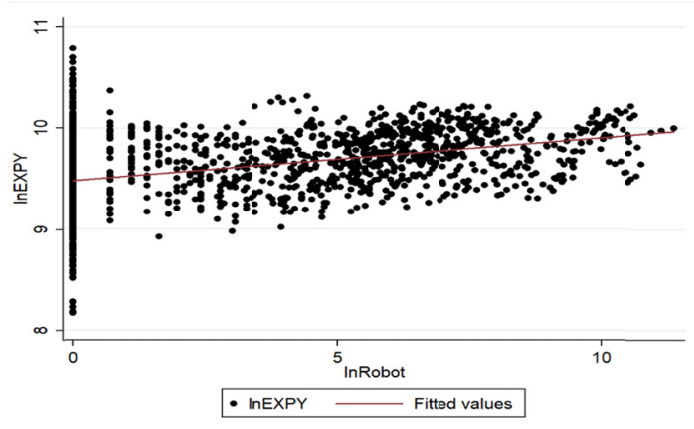

Figure 2. Scatter Plot of EXPY and Industrial Robot

\section{Results}

\subsection{Basic Results}

According to the economic model, table 2 reports the basic empirical results. In the first column, we find there is a positive relationship between industrial robots and export sophistication, statistically significant at the $99 \%$. Column 2 adds the values of log share of import and log share of inward foreign direct investment, which shows that the relation doesn't change. Column 3 controls fixed effects of countries and column 4 both controls country and year fixed effects, the effect of industrial robots still doesn't change. Column 5-6 represent the results with adding log ratio of capital, log share of aging people and log of tertiary education ratio. In all columns, we find that an increase in shipment of industrial robot in production, a faster advance in export sophistication. The founding supports the key prediction of our model, where intelligent manufacturing can realize export upgrading. From column 6, if a country's shipment number of industrial robots increases 1\%, export sophistication will increase $0.0036 \%$. The effects of other control variables are the same as literature.

Table 2. Industrial robots and export sophistication

\begin{tabular}{lllllll}
\hline & $(1)$ & $(2)$ & $(3)$ & $(4)$ & $(5)$ & $(6)$ \\
\hline lnRobot & $0.0421^{* * *}$ & $0.0405^{* * *}$ & $0.0524^{* * *}$ & $0.0037^{* *}$ & $0.0034^{* *}$ & $0.01036^{* *}$ \\
& $(0.0026)$ & $(0.0025)$ & $(0.0035)$ & $(0.0015)$ & $(0.0015)$ & $(0.0018)$ \\
lnImport & & $0.0374^{* *}$ & $0.1664^{* * *}$ & $-0.0612^{* * *}$ & $-0.0686^{* * *}$ & $-0.0593^{* * *}$ \\
& & $(0.0177)$ & $(0.0346)$ & $(0.0144)$ & $(0.0145)$ & $(0.0175)$ \\
lnIFDI & & $0.0936^{* * *}$ & $0.2513^{* * *}$ & -0.0041 & -0.0053 & -0.0065 \\
& & $(0.0096)$ & $(0.0094)$ & $(0.0050)$ & $(0.0050)$ & $(0.0059)$ \\
lnCapital & & & & & $0.0406^{* * *}$ & $0.01388^{* * *}$ \\
& & & & & $(0.0106)$ & $(0.0118)$ \\
lnAge & & & & & & -0.0469 \\
& & & & & & $(0.0379)$ \\
lnHighedu & & & & & & 0.01100 \\
& & & & & & $(0.0117)$ \\
Constant & $9.4796^{* * *}$ & $9.0569^{* * *}$ & $8.0450^{* * *}$ & $9.3923^{* * *}$ & $9.2925^{* * *}$ & $9.3292^{* * *}$ \\
& $(0.0120)$ & $(0.0543)$ & $(0.1152)$ & $(0.0499)$ & $(0.0561)$ & $(0.0981)$ \\
Country FE & NO & NO & Yes & YES & YES & YES \\
Year FE & NO & NO & NO & YES & YES & YES \\
Observations & 1,540 & 1,491 & 1,491 & 1,491 & 1,491 & $1,2.09$ \\
R-squared & 0.148 & 0.238 & 0.547 & 0.929 & 0.930 & 0.928 \\
\hline
\end{tabular}

Note. Standard errors in parentheses, ${ }^{* * *} \mathrm{p}<0.01,{ }^{* *} \mathrm{p}<0.05, * \mathrm{p}<0.1$. 


\subsection{Robustness Test}

We now give further robustness tests to show very similar results in the baseline analysis. Here the robustness checks include two kinds of proxy variables for industrial robot. We firstly use the stock of industrial robots, and then use the import value of industrial robots. Table 3 represents the impact of stock of robots on export sophistication. Column 1-6 add different control variables and fixed effects, which show us a positive relationship between stock of industrial robots and export sophistication. In column 6 , if a country's stock number of industrial robots increases $1 \%$, export sophistication will increase $0.0036 \%$. The quantitative magnitude of stock industrial robot is similar to column 6 in table 2 . So we can make sure that our result is very plausible and credible. And intelligent manufacturing indeed promotes export sophistication by widely using industrial robots.

Table 3. Stock of industrial robots and export sophistication

\begin{tabular}{lllllll}
\hline & $(1)$ & $(2)$ & $(3)$ & $(4)$ & $(5)$ & $(6)$ \\
\hline InRobot & $0.0438^{* * *}$ & $0.0418^{* * *}$ & $0.0687^{* * *}$ & $0.0029^{*}$ & $0.0027^{*}$ & $0.0036^{* *}$ \\
& $(0.0020)$ & $(0.0020)$ & $(0.0026)$ & $(0.0015)$ & $(0.0015)$ & $(0.0018)$ \\
InImport & & $0.0559^{* * *}$ & $0.1035^{* * *}$ & $-0.0588^{* * *}$ & $-0.0665^{* * *}$ & $-0.0571^{* * *}$ \\
& & $(0.0169)$ & $(0.0302)$ & $(0.0143)$ & $(0.0144)$ & $(0.0174)$ \\
InIFDI & & $0.0784^{* * *}$ & $0.1949^{* * *}$ & -0.0046 & -0.0057 & -0.0069 \\
& & $(0.0093)$ & $(0.0087)$ & $(0.0050)$ & $(0.0050)$ & $(0.0059)$ \\
InCapital & & & & & $0.0410^{* * *}$ & $0.0387^{* * *}$ \\
& & & & & $(0.0106)$ & $(0.0118)$ \\
InAge & & & & & & -0.0459 \\
& & & & & & $(0.0378)$ \\
lnHighedu & & & & & & 0.0077 \\
& & & & & & $(0.0120)$ \\
Constant & $9.4095^{* * *}$ & $8.9715^{* * *}$ & $8.2965^{* * *}$ & $9.3843^{* * *}$ & $9.2841^{* * *}$ & $9.3243^{* * *}$ \\
& $(0.0126)$ & $(0.0521)$ & $(0.1011)$ & $(0.0497)$ & $(0.0558)$ & $(0.0975)$ \\
Country FE & NO & NO & Yes & YES & YES & YES \\
Year FE & NO & NO & NO & YES & YES & YES \\
Observations & 1,540 & 1,491 & 1,491 & 1,491 & 1,491 & 1,209 \\
R-squared & 0.231 & 0.309 & 0.650 & 0.929 & 0.930 & 0.928 \\
\hline
\end{tabular}

Note. Standard errors in parentheses, ${ }^{* * *} \mathrm{p}<0.01,{ }^{* *} \mathrm{p}<0.05,{ }^{*} \mathrm{p}<0.1$.

Industrial robots are technology intensive products. Not all countries produce them. So many countries import robot technology from other countries to increase level of intelligent manufacturing. In this paper, another way of proxy variable is import value of industrial robot. It is defined by six-digit HS code 847950, firstly introduced to HS-1996 classification. Then we can calculate out import value of industrial robots for each country in the 1996-2016 period from UN Comtrade Database. Japan and Germany are the two biggest robot producer in the world (Acemoglu \& Restrepo, 2017; 2018b). A difference between them is that Japan uses domestically produced robots while Germany also use a lot of imported robots. So we only exclude Japan from our sample. Table 4 reports the relationship between import value of industrial robot and export sophistication. We can still get that if a country imports more robots, its export sophistication will increase. A country wants to improve intelligent manufacturing by using imported industrial robots to realize export upgrading. 
Table 4. Import value of industrial robots and export sophistication

\begin{tabular}{lllllll}
\hline & $(1)$ & $(2)$ & $(3)$ & $(4)$ & $(5)$ & $(6)$ \\
\hline lnRobot & $0.0450^{* * *}$ & $0.0452^{* * *}$ & $0.0708^{* * *}$ & $0.0090^{* * *}$ & $0.0081^{* * *}$ & $0.0063^{* * *}$ \\
& $(0.0034)$ & $(0.0033)$ & $(0.0046)$ & $(0.0018)$ & $(0.0018)$ & $(0.0021)$ \\
InImport & & $0.0716^{* * *}$ & $0.3371^{* * *}$ & 0.0101 & 0.0061 & -0.0059 \\
& & $(0.0178)$ & $(0.0370)$ & $(0.0142)$ & $(0.0142)$ & $(0.0162)$ \\
InIFDI & & $0.0636^{* * *}$ & $0.1862^{* * *}$ & -0.0025 & -0.0037 & -0.0081 \\
& & $(0.0112)$ & $(0.0114)$ & $(0.0048)$ & $(0.0048)$ & $(0.0054)$ \\
lnCapital & & & & & $0.0273^{* * *}$ & $0.0258^{* * *}$ \\
& & & & & $(0.0089)$ & $(0.0096)$ \\
InAge & & & & & & $0.1005^{* *}$ \\
& & & & & & $(0.0393)$ \\
InHighedu & & & & & & $0.0363^{* * *}$ \\
& & & & & & $(0.0119)$ \\
Constant & $8.9640^{* * *}$ & $8.4855^{* * *}$ & $6.6998^{* * *}$ & $9.0759^{* * *}$ & $9.0228^{* * *}$ & $8.7515^{* * *}$ \\
& $(0.0529)$ & $(0.0752)$ & $(0.1216)$ & $(0.0529)$ & $(0.0555)$ & $(0.1024)$ \\
Country FE & NO & NO & Yes & YES & YES & YES \\
Year FE & NO & NO & NO & YES & YES & YES \\
Observations & 1,162 & 1,148 & 1,148 & 1,148 & 1,148 & 966 \\
R-squared & 0.135 & 0.224 & 0.561 & 0.946 & 0.947 & 0.946 \\
\hline
\end{tabular}

Note. Standard errors in parentheses, ${ }^{* *} \mathrm{p}<0.01, * * \mathrm{p}<0.05, * \mathrm{p}<0.1$.

\subsection{Heterogeneous Analysis}

From figure 1, we know that the number of industrial robots got a big slide during 2008 financial crisis. Is there a difference in industrial robots effect before and after the financial crisis? To get the result, we decompose the sample into two parts. Table 5 reports the empirical results used flow of industrial robots. Columns 1-2 present the relationship between industrial robots and export sophistication from 1995 to 2008, while column 3-4 present from 2009-2016. From the table, we see that a significantly positive relationship is before financial crisis, while a negative relationship is after financial crisis. In column 4 , the negative effect is at $90 \%$ significance.

To make the differential effect more credible. We also use the stock of industrial robots in the model. The empirical results are reported in table 6 . We can still get that there is a significantly positive effect of robots on export sophistication before financial crisis, while a significantly negative effect after financial crisis. So we conclude that financial crisis can decrease the effect of intelligent manufacturing on export sophistication.

Table 5. The role of financial crisis between flow industrial robots and export sophistication

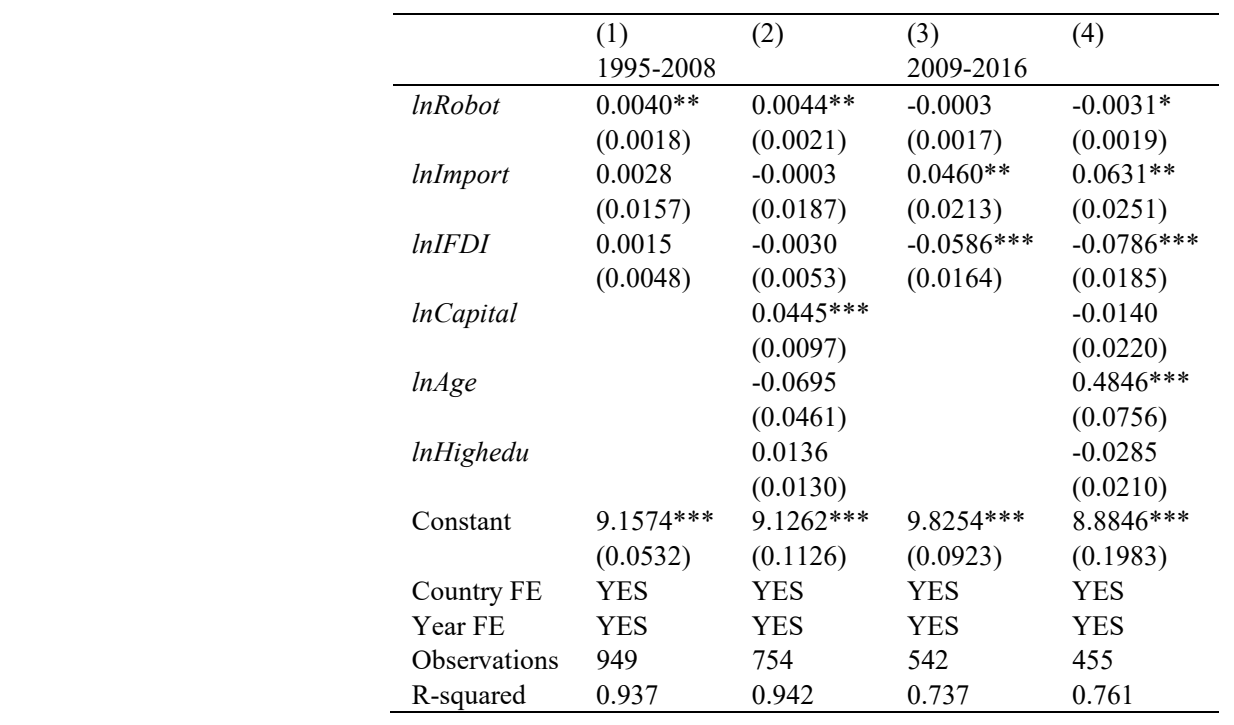

Note. Standard errors in parentheses, $* * * \mathrm{p}<0.01, * * \mathrm{p}<0.05, * \mathrm{p}<0.1$ 
Table 6.The role of financial crisis between stock industrial robots and export sophistication

\begin{tabular}{|c|c|c|c|c|}
\hline & (1) & (2) & (3) & (4) \\
\hline & \multicolumn{2}{|l|}{ 1993-2008 } & \multicolumn{2}{|l|}{$2009-2016$} \\
\hline \multirow[t]{2}{*}{ lnRobot } & $0.0032 * *$ & $0.0039 * *$ & $-0.0052^{*}$ & $-0.0070 * *$ \\
\hline & $(0.0015)$ & $(0.0018)$ & $(0.0028)$ & $(0.0028)$ \\
\hline \multirow[t]{2}{*}{ InImport } & 0.0035 & 0.0001 & $0.0457 * *$ & $0.0625^{* *}$ \\
\hline & $(0.0157)$ & $(0.0186)$ & $(0.0212)$ & $(0.0250)$ \\
\hline \multirow[t]{2}{*}{$\operatorname{lnIFDI}$} & 0.0013 & -0.0031 & $-0.0596^{* * *}$ & $-0.0769^{* * *}$ \\
\hline & $(0.0048)$ & $(0.0053)$ & $(0.0162)$ & $(0.0182)$ \\
\hline \multirow[t]{2}{*}{ InCapital } & & $0.0442 * * *$ & & -0.0137 \\
\hline & & $(0.0097)$ & & $(0.0219)$ \\
\hline \multirow[t]{2}{*}{ lnAge } & & -0.0728 & & $0.4691 * * *$ \\
\hline & & $(0.0463)$ & & $(0.0738)$ \\
\hline \multirow[t]{2}{*}{ lnHighedu } & & 0.0145 & & -0.0252 \\
\hline & & $(0.0129)$ & & $(0.0210)$ \\
\hline \multirow[t]{2}{*}{ Constant } & $9.1543 * * *$ & $9.1276^{* * *}$ & $9.8583 * * *$ & $8.9309^{* * *}$ \\
\hline & $(0.0531)$ & $(0.1124)$ & $(0.0934)$ & $(0.1965)$ \\
\hline Country FE & YES & YES & YES & YES \\
\hline Year FE & YES & YES & YES & YES \\
\hline Observations & 949 & 754 & 542 & 455 \\
\hline R-squared & 0.937 & 0.942 & 0.739 & 0.763 \\
\hline
\end{tabular}

Note. Standard errors in parentheses, ${ }^{* * *} \mathrm{p}<0.01, * * \mathrm{p}<0.05, * \mathrm{p}<0.1$.

\section{Conclusion}

The research discussed the relationship between intelligent manufacturing and export sophistication from the perspective of industrial robots. Using industrial robots panel data from International Federation of Robotics in 70 countries from 1995 to 2016, we find that intelligent manufacturing by large use of industrial robots can significantly increase a country's export sophistication. If a country increases $1 \%$ of industrial robots, export sophistication will increase $0.0036 \%$. The result that we get is very robust for stock of industrial robots and import value of industrial robots. We also find that industrial robots increase export sophistication before financial crisis, while decrease export sophistication after financial crisis.

Countries may increase industrial robot to upgrade its exporting in the new round of scientific and technological revolution. If they produce few robots domestically, they can import some robots to promote export sophistication. Developed countries have advanced robot technology, so they have a high level of intelligent manufacturing. While developing country tend to using import robots to promote intelligent manufacture. So the different countries need to take vary actions to promote the export sophistication in the age of intelligence.

\section{References}

Acemoglu, D., \& Restrepo, P. (2017). Secular stagnation? The effect of aging on economic growth in the age of automation. American Economic Review, 107(5), 174-79.

Acemoglu, D., \& Restrepo, P. (2018a). The race between man and machine: Implications of technology for growth, factor shares, and employment. American Economic Review, 108(6), 1488-1542.

Acemoglu, D., \& Restrepo, P. (2018b). Demographics and automation. NBER Working Paper.

Atkinson, R., \& Ezell, S. (2019). The manufacturing evolution: How AI will transform manufacturing and the workforce of the from https:/www.itif.org/publications/2019/08/06/manufacturing-evolution-how-ai-will-transform-manufacturin g-and-workforce

Berg, A., Buffie, E. F., \& Zanna, L. F. (2016). Robots, growth, and inequality. Finance \& Development, 53(3), $10-13$.

Berg, A., Buffie, E. F., \& Zanna, L. F. (2018). Should we fear the robot revolution? (The correct answer is yes). Journal of Monetary Economics, 97, 117-148. https://doi.org/10.1016/j.jmoneco.2018.05.014

Costinot, A., \& Werning, I. (2018). Robots, trade, and luddism: A sufficient statistic approach to optimal technology regulation. National Bureau of Economic Research. 
DeCanio, S. J. (2016). Robots and humans-complements or substitutes? Journal of Macroeconomics, 49, 280-291. http://dx.doi.org/10.1016/j.jmacro.2016.08.003

Fan, Z., Anwar, S., \& Huang, S. (2018). Cultural diversity and export sophistication. International Review of Economics \& Finance, 58, 508-522. https://doi.org/10.1016/j.iref.2018.05.008

Frey, C. B., \& Osborne, M. A. (2017). The future of employment: How susceptible are jobs to computerisation? Technological Forecasting and Social Change, 114, 254-280. http://dx.doi.org/10.1016/j.techfore.2016.08.019

Harding, T., \& Smarzynska, J. B. (2009). A touch of sophistication: FDI and unit values of exports.

Hemous, D., \& Olsen, M. (2014). The rise of the machines: Automation, horizontal innovation and income inequality, CEPR Discussion Papers.

Jarreau, J., \& Poncet, S. (2012). Export sophistication and economic growth: Evidence from China. Journal of Development Economics, 97(2), 281-292. https://doi.org/10.1016/j.jdeveco.2011.04.001

Mishra, S., Lundstrom, S., \& Anand, R. (2011). Service export sophistication and economic growth. The World Bank. https://doi.org/10.1596/1813-9450-5606

Rodrik, D. (2006). What's so special about China's exports? China \& World Economy, 14(5), 1-19. http://dx.doi.org/10.2139/ssrn.832651

Spatafora, N., Anand, R., \& Mishra, S. (2012). Structural transformation and the sophistication of Production. IMF Working Papers.

Weldemicael, E. (2014). Technology, trade costs and export sophistication. The World Economy, 37(1), 14-41.

Zhang, H., \& Yang, X. (2016). Intellectual property rights and export sophistication. Journal of International Commerce, Economics and Policy, 7(3), 1-19. https://doi.org/10.1142/S1793993316500150

Zhong, R. Y., Xu, X., Klotz, E., \& Newman, S. T. (2017). Intelligent manufacturing in the context of industry 4.0: a review. Engineering, 3(5), 616-630. https://doi.org/10.1016/J.ENG.2017.05.015

\section{Copyrights}

Copyright for this article is retained by the author(s), with first publication rights granted to the journal.

This is an open-access article distributed under the terms and conditions of the Creative Commons Attribution license (http://creativecommons.org/licenses/by/4.0/). 